Plant Tissue Cult. \& Biotech. 23(1): 11-19, 2013 (June)

$\overline{\text { PTC\&B }}$

\title{
Effects of Additives in Shoot Multiplication and Genetic Validation in Swertica chirayita Revealed through RAPD Analysis
}

\section{Vikas Sharma*, Barkha Kamal, Nidhi Srivastava, Anoop Kumar Dobriyal $^{1}$ and Vikash Singh Jadon}

Department of Biotechnology, Sardar Bhagwan Singh Post Graduate Institute of Biomedical Sciences and Research, Balawala, Dehradun, India

Key words: Swertia chirayita, Adenine sulfate, Soot multiplication, Genetic validation

\begin{abstract}
Enhanced in vitro caulogenesis has been tested in Swertia chirayita on MS supplemented with BAP, IAA, IBA, NAA and additives like adenine sulfate and d-glutamine with $2.5 \%$ sucrose. The best in vitro caulogenesis was observed in MS fortified with $4.43 \mu \mathrm{M}$ BAP in combination with IAA $(0.8 \mu \mathrm{M})$ that resulted increase in shoot multiplication rate. The multiplication and elongation of shoots were further enhanced by the addition of adenine sulfate $(0.007 \%)$ that resulted in the further increase in multiplication fold. The addition of adenine sulfate reduced the use of other cytokinins with different auxins reported in the previous studies on Swertia chirayita. The study suggests adenine sulfate as a primary assimilable reduced nitrogen source for enhancing the shoot multiplication and elongation in Swertia chirayita. RAPD markers were employed to check the genetic variation among the clonal stock that resulted in $97 \%$ similarity.
\end{abstract}

\section{Introduction}

Swertia chirayita is a medicinal plant indigenous to temperate Himalayas found at the altitude of 1,200 - 3,000 m from Kashmir to Bhutan, and in the Khasi hills in Meghalaya (Kirtikar and Basu 1984, Duke 2002). It has an increasing pharmaceutical demand due to immense medicinal properties (Sharma et al. 2011), but the low viability and germination percentage of the seeds and the necessarily delicate field handling of the seedlings are some of the factors that

*Author for correspondence: <biotech_vikas@rediffmail.com>. ${ }^{1} \mathrm{HNB}$ Garhwal Central University, Campus Pauri, Pauri Garhwal, India. 
discourage agro-technology development and, hence, commercial cultivation of Swertia chirayita. This has led to the wild extraction of plant from its natural habitat and has threatened its number in nature.

In situ propagation of the medicinal plants is limited by several factors (Jabeen et al. 2006). The potential of medicinal plants out of their natural habitat is poor. Propagation through seeds is limited with seed dormancy and depends upon rainfall, soil moisture, time of sowing etc. while vegetative propagation for these species is slow and time consuming to achieve large scale production of propagules. However, scaling up of any in vitro propagation protocol is severely hindered due to incidences of somaclonal variations. Hence, a stringent quality check in terms of genetic fidelity of progeny becomes essential. These variations arise in the cultured cells as a response to the stress imposed in tissue culture conditions.

Plant hormones have always done best with lower concentrations but the protocols used by the workers in past for Swertia chirayita have shown the effect of combinations of various cytokinins and auxins on the shoot multiplication and subsequent rooting but hardly any of them related it to the use of cytokinins and auxins along with the readily assessable additives containing adenins and amino acids that could possibly reduce the high concentration of the hormones and the negative effect of high concentration on the meristematic cell division including events of basal callusing and reduced in vitro rhizogenesis. Thus present investigation was taken up for assessing the effects of additives for enhanced rate of shoot multiplication (caulogenesis) in Swertia chirayita that has not been reported so far for this species. The clonally propagated shoots were analyzed by RAPD analysis for assessing the genetic purity.

\section{Materials and Methods}

The disease free young juvenile plants of Swertia chirayita grown ex situ were selected and collected from Hitech Nursury, Deovan, Chakrata (1400 meters), India, during the month of July. The flowering plants were dried and prepared herbarium was submitted to Botanical Survey of India, Northern Regional Centre, Dehradun (BSD) for identification up to species level and plants were given the Accession No. 113342 and identified as Swertia chirayita. Nodal segments measuring $5-8 \mathrm{~mm}$ in length were cut and sterilization was done as described by (Srivastava et al. 2010). The in vitro raised shoots were used as explant. Clonal authenticity of shoots was checked for each variable composition by random selection after each subculture and compared with the mother explant for variation through PCR-RAPD. 
The basal media comprised of the mineral salts and organic nutrients of the MS containing 2.5\% sucrose, solidified with $0.8 \%$ agar (Hi-Media, India) supplemented with different concentrations and combinations of plant growth hormones and additives. The $\mathrm{pH}$ of all media was adjusted to $5.8 \pm 2$ before autoclaving at $1.1 \mathrm{Kg} / \mathrm{cm}^{2}$. All the glassware were used of Borosil, India and chemicals were of analytical grade (HiMedia, E. Merch and Banglore Genei). Cultures were incubated at $24 \pm 2^{\circ} \mathrm{C}$ under a photoperiod of $16 \mathrm{~h} \mathrm{light} / 8 \mathrm{hrs}$ dark with a light intensity of $45 \mu \mathrm{E} / \mathrm{m}^{2} / \mathrm{s}$. Subculturing was performed at an interval of four weeks. Each treatment was replicated 24 times and all experiments were repeated at least thrice. Genomic DNA was extracted from in vitro raised plants and mother plant using the protocol described by our research group (Sharma et al. 2010). In vitro grown shoots were randomly selected from multiplication and elongation experiments and the different hormonal (additives) interactions for assessing the genetic identity and fidelity of the clonal stock. The isolated DNA was quantified and all the samples were brought down to a uniform concentration of $20 \mathrm{ng} / \mu \mathrm{l}$ to be used as template DNA for PCR

A total of 30 decamer primers were used for PCR amplification. The PCR amplification was carried out in 251 of reaction mixture in PCR tubes, in Master Cycler ${ }^{\circledR}$ Thermalcycler (Eppendorf). The optimized reaction mixture contained $2.5 \mathrm{M}$ of each dNTP (Banglore Genei), $25 \mathrm{mM} \mathrm{MgCl}$, $25 \mathrm{~m}$ primer, 20 ng DNA template and 1 unit of Taq DNA polymerase (Banglore Genei). The reaction was overlaid with mineral oil and amplification was performed. The amplification was performed by initial denaturation of template DNA at $94^{\circ} \mathrm{C}$ for $1 \mathrm{~min}$ followed by 38 cycles of $1 \mathrm{~min}$ at $94^{\circ} \mathrm{C}, 1 \mathrm{~min}$ at $35^{\circ} \mathrm{C}, 2 \mathrm{~min}$ at $72^{\circ} \mathrm{C}$ and final cycle having the final extension time of $8 \mathrm{~min}$ at $72^{\circ} \mathrm{C}$.

\section{Results and Discussion}

Explants cultured on MS supplemented with growth regulators alone or in combinations with different sets of concentrations, showed varied response that was highly significant with respect to the length and number of shoots buds obtained per explant. The effect of BAP $(0.44-13.29 \mu \mathrm{M})$ in MS and MS (free of BAP) as control towards axillary bud proliferation was significantly influenced by the concentra-tion of growth regulator (BAP) in the medium. A number of 7 - 11 shoots were observed on MS supplemented with BAP $(4.43 \mu \mathrm{M})$ after four weeks of culture (significant at $0.1 \%$ level). The number of shoots as well as the length of shoots decreased with the increase and decrease of the BAP concentration from $4.43 \mu \mathrm{M}$ (Fig. 1A). The effect of BAP was found to be favorable with respect to the induction and number of shoots in initial phase of culture establishment. The results were found to be in agreement with the 
previous reports that have showed a significant effect of BAP and other cytokinins for axillary bud proliferation (Joshi and Dhawan 2007). The shoot propagules obtained from the initial phase of culture establishment were subjected to study the effect of BAP alone and in combination with IAA (0.8 - 20 $\mu \mathrm{M})$, IBA $(0.49-12.3 \mu \mathrm{M})$ and NAA $(0.54-13.4 \mu \mathrm{M})$ for determining the optimum rate of shoot multiplication and elongation. The combination of BAP with IAA, NAA and IBA showed a significant variation for shoot regeneration and number. Out of the three auxins the best number of shoots were observed in MS supplemented with BAP $(4.43 \mu \mathrm{M})$ in combination with IAA $(0.8 \mu \mathrm{M})$. This combination gave the higher multiplication fold as compared with BAP alone (27 shoots) and the length of the shoots was observed to be $2.70 \mathrm{~cm}$. On an average 28.67 shoots were obtained with MS supplemented with BAP $(4.43 \mu \mathrm{M})$ and 2.46 $\mu \mathrm{M}$ NAA with a length of $2.07 \mathrm{~cm}$. Thirty one shoots were recorded for IBA (2.46 $\mu \mathrm{M})$ but the length of the shoots was comparable to BAP + IAA i.e. $2.67 \mathrm{~cm}$.

Effect of additives like adenine sulphate in concentration of 0.005 to $0.010 \%$ was tested in combination with BAP $(4.43 \mu \mathrm{M})$ for best in vitro caulogenesis after determining the optimal cytokinins and auxins levels for shoot bud induction, multiplication and quality of shoots (Fig. 1C). Maximum number of healthy and profuse shoot emergence was observed in MS along with BAP $(4.43 \mu \mathrm{M})$ supplemented with $0.007 \%$ adenine sulfate (Fig. 1D). The medium supplemented with adenine sulfate showed a significant increase in the rate of shoot multiplication, showing highest numbers of shoots and highest shoot length as compared to control and other concentration tested and were significant at $0.1 \%$ level. Effect of sucrose concentration was also studied to analyze the effect of adenine sulfate supplemented medium and $2.5 \%$ was found to be optimum for highest shoot multiplication (Data not shown). The concentration $(2.5 \%)$ was most effective as compare to higher concentrations of sucrose as it produced highest number of shoots (42) and length $(4.13 \mathrm{~cm})$ (significant at $0.1 \%$ level) and less incidences of basal callusing. Among all the combinations, the best shoot multiplication was observed in BAP $(4.43 \mu \mathrm{M})$ supplemented with $0.007 \%$ adenine sulphate, while the combination of NAA, IAA and IBA comparably resulted in the lowest multiplication. The superiority of BAP has been suggested over other cytokinins and auxins on medicinal plants (Dave et al. 2003, Martin 2003). There are several reasons for preferred use of BAP and slow degradation may be the one so that it can be autoclaved easily. The superiority of BAP has been established in this report while earlier reports on shoot multiplication and elongation on Swertia chirayita suggests the use of combinations of various cytokinins with $\mathrm{BAP}$ as $\mathrm{Kn}$ and $2 \mathrm{iP}$ along with auxin concentration and other components like $\mathrm{CH}$ and $\mathrm{KNO}_{3}$ (Chaudhuri et al. 2007, 
Wawrosch et al. 1999, Wang et al. 2009). The effects of higher concentration of cytokinins have been reported to reduce the number of shoots generated per explant (Wawrosch et al. 1999, Vincent et al. 1992). In the present study the use of higher concentrations of $\mathrm{Kn}$ and $2 \mathrm{iP}$ has been replaced with the supplementation of adenine sulphate at much lower concentration resulting in
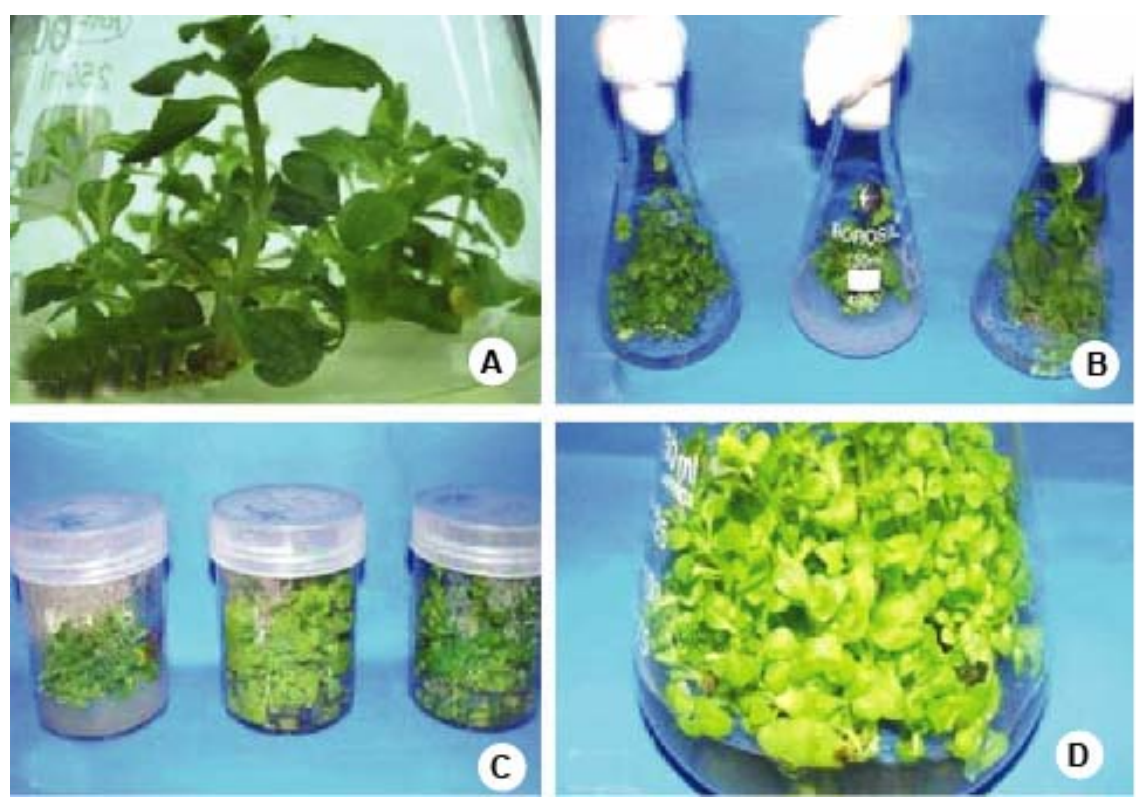

Fig. 1. In vitro shoot multiplication in Swertia chirayita. (A) Shoot multiplication in MS supplemented with BAP $(4.43 \mu \mathrm{M})$. (B) Comparison of shoot multiplication in BAP with different auxins. (C) Comparison of MS basal with MS supplemented with BAP $(4.43 \mu \mathrm{M})$ and adenine sulfate $(0.001-0.010 \%)$. (D) Best shoot multiplication in MS basal with MS supplemented with BAP $(4.43 \mu \mathrm{M})$ and adenine sulfate $(0.007 \%)$.

higher ten-fold multiplication that has not been reported so far in Swertia chirayita. Also reduction of cytokinins and auxins supplementation results in the occurrence of reduced adventitious bud formation, basal callusing and hence reducing the chances of somaclonal variations. Despite the fact that nitrates and ammonium salts have been widely used in the conventional in vitro protocols as nitrogen source, many reports suggest the use of reduced nitrogen forms particularly adenins and amino acids as these additives can adjust the nitrogen utilization of in vitro grown culture by regulating primary nitrogen assimilation and can improve cell proliferation as well as regeneration in many species (Vasudevan et al. 2004, Shrivastava et al. 2008). 
Present study was conducted to detect any event of genetic variation arisen among cultured plants due to the effect of the above mentioned cultural conditions. The components of PCR amplification were optimized for reproducible amplification of DNA using 30 random decamer primers. The primer sequences used for amplification are shown in Table 1. Three to five cloned plant propagules from multiplication tests of tissue culture protocol were selected for assessing the genetic fidelity. A total of 112 reproducible products were screened that showed no variation throughout the steps of micropropagation, justifying that the concentration of variable components imposed no variation or mutation in the in vitro raised shoots. The number of scorable bands with all primer ranged from 1 band to 7 bands in M-119 (Fig. 2A). The fragment size ranged from 0.3 to $1.5 \mathrm{~kb}$ with highest bp size in OPB-4 (Fig. 2B). The in vitro

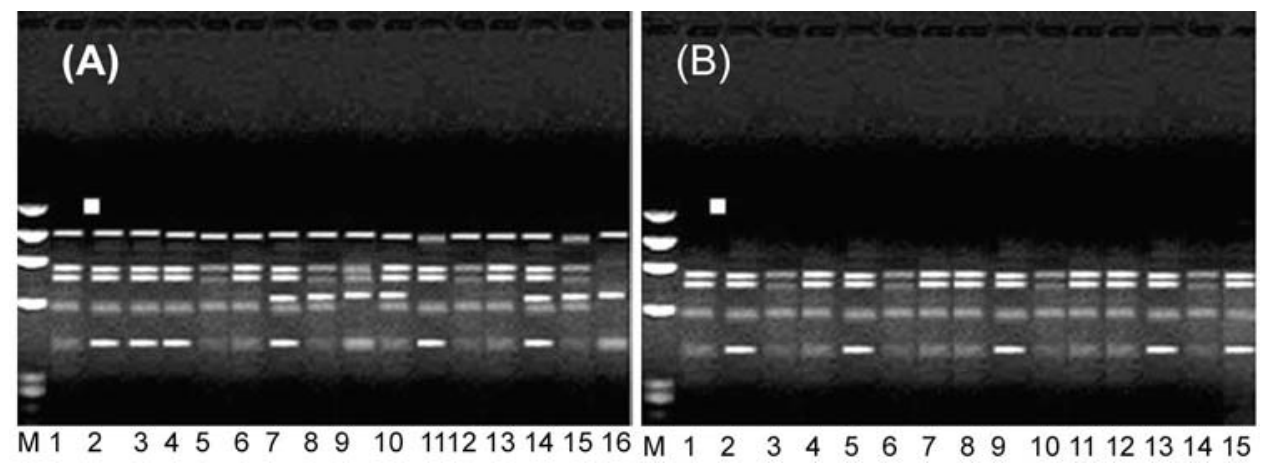

Fig. 2. RAPD fingerprinting pattern generated with primers M-119 (A) and OPB-4 (B) among the in vitro raised regenerants when compared with the donor plant. Lane (M) molecular weight marker $\varphi$ X174 Hae III digest lambda DNA, lane (1) donor plant, lane (2 - 16) micropropagated shoots.

raised shoot propagules were assessed for genetic analysis through cluster analysis along with the parental plants with Swertia cordata as an outlier and showed about $97 \%$ of similarity with the mother ex-plant of Swertia chirayita, and thus show high uniformity throughout the stock cultures with various treatments of media components during in vitro caulogenesis (Fig. 3).

The observed genetic uniformity might be ascribed to the employment of nodal segments and axillary buds as starting explant for micro-cloning as proposed for axillary and apical bud explants in many plant systems (Chaudhuri et al. 2007). Also the use of additives in present study lowers down the concentration of phytohormones and hence lowers the chances of somaclonal variations. Since in vitro multiplication or caulogenesis is one of the key parameters for the successful tissue culture protocol, genetic validation of the 
Table 1. RAPD primers used and amplicons generated by 30 decamer primers in Swertia chirayita.

\begin{tabular}{|c|c|c|c|}
\hline $\begin{array}{l}\text { Sl. } \\
\text { No. }\end{array}$ & $\begin{array}{l}\text { Primer sequence } \\
\left(5^{\prime}-3^{\prime}\right)\end{array}$ & $\begin{array}{l}\text { Total No. of } \\
\text { amplicons }\end{array}$ & $\begin{array}{l}\text { Mol. wt.t } \\
(\mathrm{kb})\end{array}$ \\
\hline 1 & M-29- CCGGCCTTA C & 4 & $0.4-1.2$ \\
\hline 2 & M-31- CCGGCCTTC C & 3 & $0.3-1.2$ \\
\hline 3 & M-33- CCGGCTGGA A & 4 & $0.3-0.8$ \\
\hline 4 & M-119- ATT GGG CGA T & 7 & $0.3-1.0$ \\
\hline 5 & M-66- GAG GGC GTG A & 0 & 0.0 \\
\hline 6 & M-82- GCG CCC GAG G & 3 & $0.5-0.9$ \\
\hline 7 & M-83- GGG CTC GTG G & 4 & $0.3-1.2$ \\
\hline 8 & M-110- TAG CCC GCT T & 4 & $0.3-1.0$ \\
\hline 9 & M-116- TAC GAT GAC G & 5 & $0.4-1.2$ \\
\hline 10 & M-122- GTAGACGAG C & 0 & 0.0 \\
\hline 11 & M-169- ACGACGTAG G & 0 & 0.0 \\
\hline 12 & M-186- GTGCGTCGC T & 1 & 0.7 \\
\hline 13 & M-188- GCTGGACAT C & 3 & $0.4-0.7$ \\
\hline 14 & M-191- CGATGGCTT T & 1 & 0.4 \\
\hline 15 & M-131- GAA ACA GCG T & 6 & $0.3-1.2$ \\
\hline 16 & M-132- AGG GAT CTC C & 5 & $0.3-1.2$ \\
\hline 17 & M-147- GTG CGT CCT C & 4 & $0.3-0.9$ \\
\hline 18 & OPA-2- TGCCGAGCTG & 4 & $0.3-1.0$ \\
\hline 19 & OPA-8- GTGACGTAGG & 4 & $0.4-1.2$ \\
\hline 20 & OPA10- GTGATCGCAG & 3 & $0.6-1.0$ \\
\hline 21 & OPA 4- AATCGGGCTG & 6 & $0.4-1.4$ \\
\hline 22 & OPB 1- GTTTCGCTCC & 4 & $0.3-0.7$ \\
\hline 23 & OPB 2- TGATCCCTGG & 4 & $0.3-1.1$ \\
\hline 24 & OPB 3- TGATCCCTGG & 3 & $0.4-0.7$ \\
\hline 25 & OPB 4- GGACTGGAGT & 6 & $0.4-1.5$ \\
\hline 26 & OPB 5- TGCGCCCTTC & 2 & $0.4-0.5$ \\
\hline 27 & OPB 6- TGCTCTGCCC & 4 & $0.3-0.9$ \\
\hline 28 & OPB 7- GGTGACGCAG & 7 & $0.5-1.4$ \\
\hline 29 & OPB 8- GTCCACACGG & 4 & $0.3-1.0$ \\
\hline 30 & OPA 1- CAGGCCCTTC & 5 & $0.4-1.2$ \\
\hline \multicolumn{2}{|c|}{ Total number } & 112 & \\
\hline
\end{tabular}

cloned stock further ensures the genetically identity and relatedness with the parental plants. As production of genetically true to type plants is a prerequisite for the conservation and propagation programme for the endangered plant 
species. Thus present protocol provides the clear genetic status of the in vitro raised propagules where the fidelity of the plants was maintained throughout the stock.

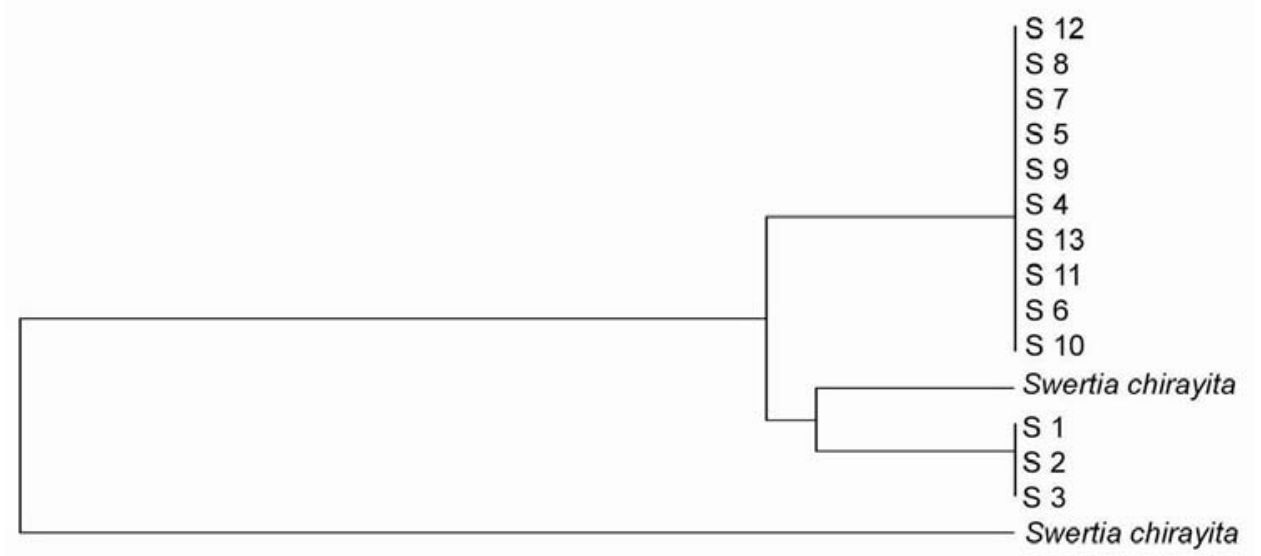

Fig. 3. Dendogram generated by UPGMA cluster analysis for similarity matrix obtained by Jaccard's genetic distance for 13 random samples obtained during in vitro caulogenesis.

\section{Acknowledgement}

The authors are thankful to management of SBSPGI, Balawala, Dehradun for providing necessary facilities for carrying out the experiments. The financial assistance from UCOST, Dehradun is duly acknowledged.

\section{References}

Kirtikar KR and Basu BD (1984) (eds). Indian Medicinal Plants. Allahabad, vol. III, pp. 1664-1666.

Duke JA (2002) Handbook of Medicinal Herbs. 2nd Edn. CRC Press, Boca Raton, FL, USA, ISBN: 0849312795. pp. 896.

Sharma V, Srivastava N, Kamal B, Dobriyal AK and Jadon VS (2011) Swertia chirayita: A review to revitalize its importance in pharmaceutical arena. Jour. Pharm. Res. 4: 17841787.

Jabeen N, Shawl AS, Dar GH and Sultan P (2006) Callus induction and organogenesis from explants of Aconitum heterophyllum medicinal plant. Biotechnology 5: 287-291.

Srivastava N, Kamal B, Sharma V, Negi YK, Dobriyal AK, Gupta S and Jadon VS (2010) Standardization of sterilization protocol for micropropagation of Aconitum heterophyllum - An endangered medicinal herb. Academic Arena 2: 37-42. 
Sharma V, Srivastava N, Kamal B, Dobriyal AK and Jadon VS (2010) Isolation of PCR compatible DNA from Swertia chirayita. Asian J. Micro. Biotech. \& Env. Sci. 12: 677680.

Joshi P and Dhawan V (2007) Axillary multiplication of Swertia chirayita (Roxb. Ex Fleming) H. Karst., a critically endangered medicinal herb of the temperate Himalayas. In Vitro Cell and Dev. Bio. Plant. 43: 631-638.

Dave A, Bilochi G and Purohit SD (2003) Scaling-up production and field performance of micropropagated medicinal herb 'Safed Musli' (Chlorophytum borivilianum). In Vitro Cell and Dev. Bio. Plant. 39: 419-424.

Martin KP (2003) Rapid in vitro multiplication and ex vitro rooting of Rotula aquatica Lour., a rare rhoeophytic woody medicinal plant. Plant Cell Reports 21: 415-420.

Chaudhuri RK, Pal A, Jha TB (2007) Production of genetically uniform plants from the nodal explants of Swertia chirayita Buch.-Ham. ex Wall.- an endangered medicinal herb. In Vitro Cell and Dev. Bio. - Plant. 43: 467-472.

Wawrosch C, Maskay N and Kopp B (1999) Micropropagation of the threatened Nepalese medicinal plant Swertia chirata Buch.-Ham.ex Wall. Plant Cell Reports. 18: 997-1001.

Wang Li, An Li, Yanping H, Wei L, Li Y (2009) Influence of phytohormones and medium on shoot regeneration from leaf of Swertia chirata Buch.-Ham. ex Wall. In vitro. African J. Biotech. 8: 2513-2517.

Vincent KA, Mathew KM and Hariharan M (1992) Micropropagation of Kaempferia galanga L. - A medicinal plant. Plant Cell Tiss. Org. Cult. 28: 229-230.

Vasudevan A, Selvaraj N, Ganapathi A, Kasthurirengan S, Anbazhagan VR and Manickavasagam M (2004) Glutamine: A suitable nitrogen source for enhanced shoot multiplication Cucumis sativus L. Biologia Platarum 48: 125-128.

Shrivastava S and Banerjee M (2008) In vitro clonal propagation of physic nut (Jatropha curcas L.): Influence of additives. International Journal of Integrative Biology 3: 73-79. 